\title{
Learning Motivation, Media, and Reading Ability on Student Achievement in Social Science
}

\author{
Nurfiyati, Ninik Indawati* \\ Master of Social Science Education Study Program \\ Universitas Kanjuruhan Malang \\ Malang, Indonesia \\ nurfiyati11111975@gmail.com,*ninikberty@unikama.ac.id
}

\begin{abstract}
This study aimed to investigate the contribution of learning motivation, learning media, students reading ability to students' learning outcomes in social science. This study used a quantitative approach with research variables including learning motivation, learning media, and reading ability. The research respondents were 90 students, selected using the total sampling technique. The research instruments consisted of an independent variable questionnaire and the results of the students' daily tests. Data analysis was performed using multiple regression analysis, classic assumption tests and hypothesis testing. The results showed that learning motivation, learning media and reading ability had an effect on student achievement in social science $(\mathbf{9 9 . 8 \% )}$. Teachers should be able to increase student enthusiasm and motivation in learning through the provision of learning media and books.
\end{abstract}

Keywords-learning motivation, media, reading ability, achievement in social studies

\section{INTRODUCTION}

Learning motivation, learning media, and reading skills are some of the factors that determine student learning success. If the learning process does not find this, of course it is an obstacle in achieving effective learning outcomes for students. An effective learning process is needed for teachers to maximize student learning outcomes. The teacher needs to develop all the potential that students have, provide guidance and always provide motivation and confidence to students so that they are able to master the subject matter taught in school. Apart from motivation, students also need learning media to make it easier for teachers to deliver material. The teaching and learning process can be boring and tedious if students are not given motivation to learn. An LCD and supporting books can help maximize student success in learning.

Based on previous research, there are similarities and differences in research with those to be carried out by the researchers. The equation is both testing the effect of independent variables on the dependent variable, while the difference is that previous research only tested the effect partially, while research conducted by researchers would test both partially and simultaneously between the independent variables and the dependent variable.

Students are the main subject of learning, so the teaching and learning process must always pay attention to the characteristics and needs of the students. In the teaching and learning process the teacher acts as a facilitator who helps students develop themselves, encourages students to grow and develop into personality citizens and develop social skills. The activeness of students should be encouraged by the willingness to learn because there is something to be achieved and will develop if it is based on the utilization of their potential (intrinsic motivation). Meanwhile, the teacher helps motivate and provide guidance that leads to the goals to be achieved (extrinsic motivation) [1,2].

Motivation to learn is the main factor that determines the success of learning. The level of motivation is largely determined by the level of meaningfulness of the learning materials and learning activities of the students concerned $[1,2]$. Motivation is the driving force to be active, to be active at certain times, especially when the need to achieve goals is felt / urgent $[3,4]$. To conclude that motivation is the entire driving force, both from within and from outside by creating a series of efforts to provide certain conditions that ensure continuity and provide direction to activities so that the goals desired by the subject can be achieved. Motivation comes from motive which means anything that encourages someone to act to do something. In addition to motivation in learning to improve student learning outcomes, learning media are also needed, one of which is LCD [5,6] merging or integrating two or more integrated formats such as text, animation, and video to form information rules into a computer system.

Learning media is a complex process to facilitate student learning [3,7]. Thus the learning media is essentially to facilitate student learning including media models and blackboards [1,6] things that need to be considered or some principles that need to be considered by teachers / educators in selecting and using learning media [8,9]. Read a lot of textbooks, many are known, meaning that those who read a lot of textbooks will understand and master everything more than those who do not read much. 
Reading is the process of critical-creative reading processing carried out with the aim of obtaining a comprehensive understanding of the reading, and assessing the state of the reading's function value and impact $[1,8]$.

The effectiveness of a learning model, of course, cannot only be based on the results of one study, but it requires a review of other similar studies. This review will be useful for researchers in conducting research related to learning motivation, learning media, and reading skills are some of the factors that determine student learning success. This review aims to analyze the effect of learning motivation, instructional media, and reading ability on social studies learning outcomes in class XI IPS SMAN students. The success of the influence of learning motivation, learning media, and reading ability on social studies learning outcomes in class XI IPS SMAN depends on the research design applied. By examining learning motivation, learning media, and reading ability on social studies learning outcomes in class XI IPS SMAN students will produce the best information and can be scientifically accounted for, so that it can be applied to other schools in relevant class XI IPS students.

Developing all the potential that students have, providing guidance and always providing motivation and confidence in their students that students can certainly master the subject matter taught in school, apart from student motivation also requires learning media, where learning media is supporting material tools that make it easier for teachers to deliver material. In the teaching and learning process it will be boring and saturating so that students must be motivated and equipped with an LCD as a function of learning media and students are given supporting books so that students can be enthusiastic in the teaching and learning process.

The purpose of this study was to analyze the effect of learning motivation, learning media, and reading ability partially or jointly on the learning outcomes of Geography students in class XI SMA.

\section{METHODS}

This study used a quantitative approach. The total sampling method was used to select 90 students. The data were collected using a questionnaire. The data were analyzed using multiple regression analysis, classic assumption test and hypothesis testing. Multiple regression analysis was run to determine the effect of the independent variables (the effect of learning motivation, learning media and the ability to read books) on the dependent variable (learning outcomes). The classic assumption tests used were normality test, multicollinearity test, heteroscedasticity test, autocorrelation test. Meanwhile, the hypothesis was tested using the t-test, $F$ test and determination (R2). The t-test in this study was conducted to determine the significance level of learning motivation (X1) on learning outcomes $(\mathrm{Y})$, and learning media (X2) on learning outcomes (Y) and the ability to read books (X3) on learning outcomes (Y). The F test in this study was used to determine the significant level of learning motivation (X1) learning outcomes (Y), and learning media (X2) on learning outcomes (Y) and the ability to read books (X3) on learning outcomes (Y). Determination (R2) reflects how much the variance of the dependent variable (Y) can be explained by the independent variable $(\mathrm{X})$

\section{RESULTS AND DISCUSSION}

\section{A. Results}

Classical Assumption Test. The use of regression as an analysis model must fulfill some basic assumptions (Classical Assumptions), in order to obtain an unusual estimator from regression with ordinary least squares. In accordance with the statistical analysis techniques that will be used in this study, a classical assumption tests which consist of a normality test, a multicollinearity test and a heteroscedasticity test were conducted. The data were analyzed using the SPSS 20 program. The results are presented below.

Normality Test. The results of the Normal P-P Plot of regression standardized Residual are depicted in Figure 1. It can be seen that the data are spread around the diagonal line, and the direction of the distribution follows the direction of the diagonal line (bottom left to top right). Thus, it can be stated that the data are normally distributed.

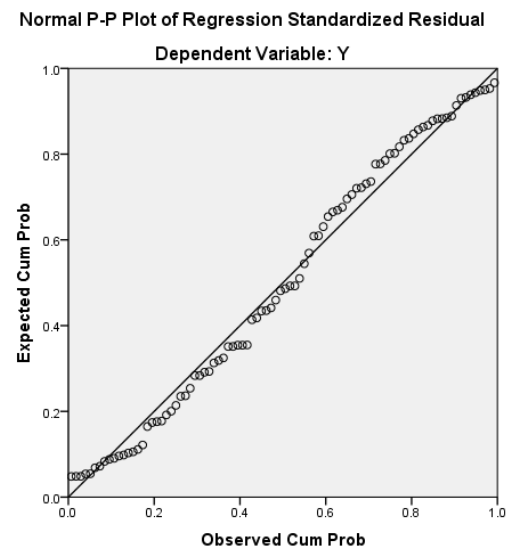

Fig. 1. Residual normality plot.

1) Multicollinearity test: Based on Table 1, the VIF value is 1.014 , for the learning media variable, the VIF value is 1.033 and the VIF value book reading ability variable is 1.046 . The VIF value for each variable is smaller than 10 so that the three variables are not perfectly correlated, thus it is stated that there is no multicollinearity symptom in the regression model. 
TABLE I. COEFFICIENT VALUE (B I)^AND VIF VALUE ON EACH VARIABLE

\begin{tabular}{|l|l|l|l|l|}
\hline \multicolumn{1}{|c|}{$\widehat{\beta_{0}}$} & \multicolumn{1}{c|}{ Value $\widehat{\beta_{0}}$} & \multicolumn{1}{c|}{ Value $\boldsymbol{t}_{\text {count }}$} & p-value & \multicolumn{1}{c|}{ VIF } \\
\hline$\widetilde{\beta_{0}}($ konstanta $)$ & 0,163 & 0,300 & 0,765 & - \\
\hline$\widetilde{\beta_{1}}\left(X_{1}\right)$ & 0,758 & 140,862 & 0,000 & 1,014 \\
\hline$\widetilde{\beta_{2}}\left(X_{2}\right)$ & 1,087 & 109,074 & 0,000 & 1,033 \\
\hline$\widetilde{\beta_{\mathrm{a}}\left(X_{3}\right)}$ & 0,567 & 57,890 & 0,000 & 1,046 \\
\hline
\end{tabular}

2) Heteroscedasticity test: Based on Figure 2, the data distribution does not form a certain pattern (random). Since the data distribution does not form a certain pattern, it can be stated that there are no heteroscedasticity symptoms in the regression model.

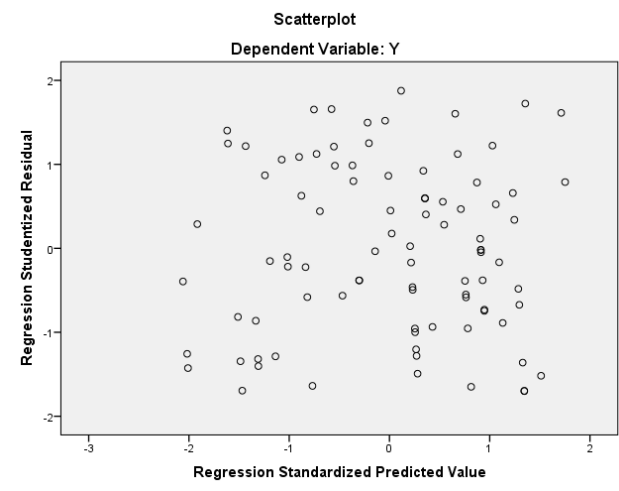

Fig. 2. Residual plots with predicted value.

3) Autocorrelation test: Autocorrelation symptoms can be detected through the Durbin Watson (d) test. The results of Durbin Watson's (d) calculation are compared with the d table at $\alpha=0.05$. Based on Table 2, Durbin Watson's calculation (d) $=2.005$, while the upper limit value $(\mathrm{du})=1.5889$. Since the value of Durbin Watson (d) is greater than the value of du and less than the value of $4-\mathrm{du}(1.5889<2.005<2.4111)$, it can be stated that there is no autocorrelation.

TABLE II. RADJ VALUE AND DURBIN WATSON VALUE

\begin{tabular}{|c|c|c|}
\hline $\begin{array}{c}\text { Adjusted R } \\
\text { Square }\end{array}$ & $\begin{array}{c}\text { Std. Error of the } \\
\text { Estimate }\end{array}$ & $\begin{array}{c}\text { Durbin- } \\
\text { Watson }\end{array}$ \\
\hline 0,998 & 0,284 & 2,005 \\
\hline
\end{tabular}

\section{4) Hypothesis testing}

a) Multiple linear regression analysis (Multiple regression): Multiple regression analysis is used to determine the effect of the independent variables (learning motivation, learning media and the ability to read books) on the dependent variable (learning outcomes). The multiple linear regression equations are presented as follows:

- A constant of 0.163 means that if there is no learning motivation (X1), learning media (X2) and the ability to read books (X3), then the learning outcome is 0.163 .
- The regression coefficient $\mathrm{X} 1=0.758$ shows the magnitude of the influence of learning motivation on learning outcomes, the regression coefficient is positive which means that learning media has a positive effect (unidirectional), meaning that an increase in learning motivation 1 unit will lead to an increase in learning outcomes of 0.758 units or vice versa.

- The regression coefficient X2 $=1.087$. Indicates the magnitude of the influence of the learning media on learning outcomes, the regression coefficient is positive which means that the learning media has a positive effect (unidirectional), meaning that an increase in learning media 1 unit will cause an increase in learning outcomes by 1.087 units or vice versa.

- The regression coefficient $\mathrm{X} 3=0.567$ shows the magnitude of the influence of the ability to read books on learning outcomes, the regression coefficient is positive which means that the ability to read books has a positive effect (unidirectional) meaning that an increase in the ability to read books 1 unit will lead to an increase in learning outcomes by 0.567 units or vice versa.

\section{5) $F$ test (Anova)}

TABLE III. F-TeSt VALUE ON THE REgRESSION MOdEL

\begin{tabular}{|l|l|l|l|l|l|}
\hline \multicolumn{1}{|c|}{ Model } & $\begin{array}{c}\text { Sum of } \\
\text { Squares }\end{array}$ & $\mathbf{F}$ & $\begin{array}{c}\text { Mean } \\
\text { Square }\end{array}$ & F & p-value \\
\hline regression & 2878,230 & 3 & 959,410 & 11913,757 & 0,000 \\
\hline Residual & 6,926 & 6 & 0,081 & & \\
\hline Total & 2885,156 & 9 & & & \\
\hline
\end{tabular}

6) $T$ test

The results of the t test can be concluded as follows:

- Testing the learning motivation hypothesis (X1) on Learning Outcomes (Y). Based on Table 1, it is obtained that the value of $\mathrm{t}=140.862$ while $\mathrm{t}$ table $=$ 1.98761 because the value of tcount $>$ ttable is that Ho is rejected and $\mathrm{Ha}$ is accepted, meaning that learning motivation (X1) has a significant effect on learning outcomes

- Hypothesis testing of learning media (X2) on Learning Outcomes (Y). Based on Table 1, it is obtained the value of $\mathrm{t}=109.074$ while $\mathrm{t}$ table $=1.98761$ because tcount> ttable, 1 then Ho is rejected and Ha is accepted, meaning that the learning media (X2) has a significant effect on learning outcomes.

- Hypothesis testing of the ability to read books (X3) on Learning Outcomes (Y).

Based on Table 1 , the value of tcount $=57,890$, while ttable $=1.98761$ because tcount $>$ ttable, then Ho is rejected and Ha is accepted, meaning that the ability to read books (X3) has a significant effect on learning outcomes. 
Based on this test, the independent variable that most influences learning outcomes is learning motivation, because the beta value (Standardized Coefficients value) learning motivation has the greatest value so that it has a dominant influence on the dependent variable.

7) Determination coefficient analysis (R2 test): Based on the research through the analysis of the Summary model, the $\mathrm{R}$ Square figure is the $\mathrm{R}$ square adjusted value, because the $\mathrm{X}$ variable is more than one. The R2 value based on Table 2 is 0.998 or $99.8 \%$. This means that $99.8 \%$ of the learning outcomes (Y) can be explained by the learning motivation variable (X1), learning media (X2), and the ability to read books $(\mathrm{X} 3)$, and the rest $(100 \%-99.8 \%)=0,2 \%$ is influenced by other factors, outside the variables studied.

The results of multiple regression analysis can be explained as follows:

- Based on the above data, the value of Sig. $000<0.05$ means that Ho is rejected (Ha is accepted) which means learning motivation, learning intervals and the ability to read books together (simultaneously) have a significant effect on learning outcomes.

- The value of R2 shows that learning outcomes (Y) can be explained $99.8 \%$ by the learning motivation variable (X1), learning media (X2), the ability to read books (X3), and the rest $(100 \%-99.8 \%)=0.2 \%$ is influenced by other factors.

- A constant of 0.163 means that the value of learning motivation (X1), learning media (X2) and the ability to read books (X3) on students' learning outcomes is 0.163 .

\section{B. Discussion}

Learning motivation, learning media and the ability to read books simultaneously have an effect on learning outcomes. This is based on the results of multiple regression analysis which can be explained as follows:

Based on the results of the research, it was obtained that the value of the Fcount value was 11913.757 while the Ftable value at the level of $\alpha=0.05$ degrees of freedom $=3: 87$ was 2.71, then Fcount was 11913.757> Ftable 2.71. Therefore, Ho was rejected (Ha accepted), indicating that learning motivation, learning media and the ability to read books together (simultaneously) have a significant effect on learning outcomes.

The coefficient of determination of R Square of the number $\mathrm{R}$ Square is 0.998 . This means that $0.998 \%$ of the learning outcomes (Y) can be explained by the learning motivation variable (X1), learning media (X2), and the ability to read books $(\mathrm{X} 3)$, and the rest $(100 \%-99.8 \%)=0.2 \%$ is influenced by other factors. This suggests that even though the teacher provides learning motivation, learning media and the ability to read books to the fullest, there are other factors that do affect learning outcomes.
Based on the results of the discussion above, it can be concluded that learning motivation, learning media and the ability to read books together have an effect on learning outcomes. Therefore, teachers should be more oriented towards active student involvement by always providing motivation with learning media and improving students' ability to read books to the fullest.

The results of the study reflect the importance of learning motivation [10,11] and learning media. Mastering these media, responding creatively to technological developments and using them as a medium to strengthen and maximize learning outcomes are things that should be done by teachers. Teachers need to understand how to operate a computer, use the internet and utilize various types of media $[12,13]$.

This study also reveals that students' reading ability may influence learning outcomes [8,9]. The ability to read and write is the main basis not only for teaching the language itself but also for teaching other subjects. Motivation to learn and read books certainly have an effect on students' learning outcomes $[14,15]$.

1) The effect of learning motivation on learning outcomes: Partially the correlation coefficient X1 (learning motivation) has a significant effect on variable $\mathrm{Y}$ (learning outcomes). This is indicated by the results of the analysis obtained by the value of $\mathrm{t}=140.862$ while $\mathrm{t}$ table $=1.98761$, hence Ho is rejected and $\mathrm{Ha}$ is accepted. It suggests that that learning motivation (X1) has a significant effect on learning outcomes.

The regression coefficient $(\mathrm{X} 1=0.758)$ shows the significance of the effect of learning motivation on learning outcomes. Since the regression coefficient is positive, it can be concluded that a unit of learning motivation can result in an increase in learning outcomes by 0.758 units or vice versa.

This study has revealed that the most important influence on learning outcomes is learning motivation because the $t$ value is greater than the learning media and the ability to read books (0.163).

Based on the data analysis as described above, it can be concluded that students must be trained through effective learning that can motivate them. In addition, students are also expected to be more creative in learning.

The results above reflect the importance of learning motivation [10,11]. Learning media are generally used to provide clarity and facilitate the teaching and learning process, and can activate interaction communication between teachers and students, and can stimulate thoughts, attention, and the desire of students to achieve success in learning.

Research on the effect of motivation on student learning outcomes [14,15]. Kemendikbud [2] and Suprihatin [4], concluded that there is a positive and significant influence of motivation on learning outcomes.

2) The effect of learning media on learning outcomes: Partially the correlation coefficient X2 (instructional media) 
has a significant effect on variable Y (learning outcomes). This is indicated by the results of the analysis obtained by the value of $t=109.074$ while $t$ table $=1.98761$ or tcount $>t$ table, hence $\mathrm{Ho}$ is rejected and $\mathrm{Ha}$ is accepted. This finding indicates that the learning media (X2) has a significant effect on students' learning outcomes.

The regression coefficient $(\mathrm{X} 2=1.087)$ that learning media have a positive contribution towards learning outcomes (unidirectional). An increase in 1 unit of learning media will lead to an increase in learning outcomes by 1.087 units or vice versa.

Based on the data analysis above, it can be concluded that learning media can affect learning outcomes. Learning media have an important position in improving learning outcomes. The method of giving assignments and recitation is "a way of presenting learning materials by giving assignments to students to be done outside the school schedule within a certain period of time and the results must be accounted for (reported) to the teacher" [16,17].

3) The effect of reading ability on learning outcomes: The result of multiple regression analysis shows that reading ability has a significant effect on the variable Y (Learning Outcomes). This is indicated by the value of tcount $=57.890$ while ttable $=1.98761$ or tcount $>$ ttable, that suggests to reject Ho and accept Ha. Based on these figures, it can be concluded that reading ability has has a significant effect. on learning outcomes.

The regression coefficient $(\mathrm{X} 3=0.567)$ shows that reading ability has a positive correlation with students' learning outcomes. The statistical analysis showed that an increase in a unit of reading ability will result in an increase in learning outcomes by 0.567 units or vice versa.

Based on the data analysis above, it can be concluded that reading ability may affect students' learning outcomes. The research findings above reflect the importance of basic reading skills. The results of this study are in line with past studies that found a positive and significant effect of the ability to read books on students' learning outcomes $[8,18]$.

\section{CONCLUSION}

The results of the study suggest that learning motivation, learning media and the ability to read books simultaneously have an effect on students' learning outcomes. Apart from that, the multiple regression analysis showed that $99.8 \%$ of learning outcomes were affected by learning motivation, media and reading ability, while the remaining $0.2 \%$ was influenced by other factors outside the independent variables examined in this study.

Partially, there is a significant influence of learning motivation and learning media on students' learning outcomes.
High motivation and more varied media play a key role in improving students' learning outcomes. Reading ability also has a significant contribution towards students' learning outcomes. High reading ability leads to better learning outcomes.

\section{REFERENCES}

[1] N.S. Degeng, Belajar Mengajar Quantum. Surabaya: Adi Buana, 2011

[2] Kemendikbud, Melalui Pendekatan Pembelajaran Geografi Melalui Pendekatan Sainfifik, Direktorat Pembinaan SMA. Jakarta: Kemendikbud, 2014.

[3] G. Isnani, "The Influence of Classroom Climate, Learning Interest, Learning Discipline and Learning Motivation to Learning Outcomes on Productive Subjects," JPBM (Jurnal Pendidikan Bisnis dan Manajemen), vol. 3, no. (2), pp. 85-96, 2017.

[4] S. Suprihatin, "Upaya guru dalam meningkatkan motivasi belajar siswa," Jurnal Pendidikan Ekonomi UM Metro, vol. 3, no. (1), pp. 73 82, 2015.

[5] A.T. Prasasty, "Pengaruh disiplin dan motivasi belajar terhadap prestasi belajar matematika siswa kelas X SMK Bina Karya Insan Tangerang Selatan," UTILITY: Jurnal Ilmiah Pendidikan Dan Ekonomi, vol. 1, no. (1), pp. 65-74, 2017.

[6] A. Arsyad, Media Pembelajaran. Cet. 17. Jakarta: PT. Raja Grafindo, 2014.

[7] Sardiman, Interaksi dan Motivasi Belajar Mengajar. Ed. 1. Cet. 23 Jakarta: Rajawali Press, 2016.

[8] D. Fitriah, "Hubungan kemampuan membaca buku teks dan keterampilan berpikir kritis dengan hasil belajar pendidikan agama islam," Studia Didaktika, vol. 11, no. (01), pp. 91-110, 2017.

[9] Nurhadi, Strategi meningkatkan daya baca. Jakarta: Bumi Aksara, 2016.

[10] F. Angraini, S. Nas, and S. Sumarno, "The effect of Learning Facility, Attention of Parents, and Learning Motivation on Student Achievement at State Senior High School 2 Kampar District," International Journal Of Economics, Business And Applications, vol. 3, no. (2), pp. 12-23, 2018.

[11] F. Pupuh, Supervisi Pendidikan. Bandung: Refika Aditama, 2011.

[12] E. Anggraini, Pengaruh Pergaulan Teman Sebaya dan Motivasi Belajar Terhadap Hasil Belajar Ekonomi Siswa Kelas XI Ilmu Pengetahuan Sosial Sekolah Menengah Atas Negeri 1 Sukodono Tahun Ajaran 2013/2014. Doctoral dissertation, Surakarta: Universitas Muhammadiyah Surakarta, 2015.

[13] N. Naim, Menjadi Guru Inpriratif. Yogyakarta: Pustaka Pelajar, 2016.

[14] D.K. Korir and F. Kipkemboi, "The impact of school environment and peer influences on students' academic performance in Vihiga County, Kenya," 2014

[15] F. Daud, "Pengaruh kecerdasan emosional (EQ) dan motivasi belajar terhadap hasil belajar Biologi siswa SMA 3 Negeri Kota Palopo," Jurna Pendidikan dan Pembelajaran (JPP), vol. 19, no. (2), pp. 243-255, 2012.

[16] N. Mahnun, "Media pembelajaran (kajian terhadap langkah-langkah pemilihan media dan implementasinya dalam pembelajaran)," An-Nida', vol. 37, no. (1), pp. 27-34, 2012.

[17] Slameto, Belajar dan Faktor-faktor Yang Mempengaruhinya. Jakarta: PT. Rineka Cipta, 2010.

[18] M.I. Azhim, "Value of Students' Study Motivation on Geography Lesson In SMA Gowa Raya Sungguminasa Kabupaten Gowa," UNM Geographic Journal, vol. 1, no. 1, pp. 41- 47, 2017. 